\title{
The Assembly Enterprises in the Electric Electronic Sector in Tamaulipas, Mexico: Their Knowledge Ties
}

\author{
Francisco García Fernández ${ }^{1}$, José Ángel Sevilla Morales ${ }^{1}$, Jesús Gerardo Delgado Rivas ${ }^{1}$ \& Mónica Lorena \\ Sánchez Limón ${ }^{1}$ \\ ${ }^{1}$ Researcher at the Autonomous University of Tamaulipas, Ciudad Victoria, Tamaulipas, Mexico \\ Correspondence: José Angel Sevilla Morales, Faculty of Commerce and Administration, Autonomous University \\ of Tamaulipas, Ciudad Victoria, Tamaulipas, Mexico. E-mail: sevilla30@hotmail.com
}

Received: January 27, 2017

doi:10.5539/ijbm.v12n5p64
Accepted: March 29, 2017 Online Published: April 27, 2017

URL: https://doi.org/10.5539/ijbm.v12n5p64

\begin{abstract}
This work's objective is to identify, and to classify the different types of bonds established between the assembly enterprises in the electric electronic sector in Tamaulipas with the local and foreign agents. The work is supported in a multicase study methodology. The methodology is applied by Marin and Giuliani (2006) that allows them to measure the bonds looking for the frequency, stability, the degree of cohesion, the fragility of the relationships, the interoperability, the interdependence of the diverse agents of study, and also its graphic representation through the Netdraw software. The classification of the enterprises involved in the study was obtained with the enterprises with fragile local ties and strong bonds with their headquarters. The evaluation of these bonds allowed them to classify them as globally diversified (enterprises A and B); Globally dependent (C); Globally Independent (E); and Globally Isolated (E).
\end{abstract}

Keywords: bonds, knowledge; assembly enterprises; electric electronic sector, Tamaulipas

\section{Introduction}

Tamaulipas' border has an economy based on the exporting assembly industry. This is a type of industry that is highly dependent on direct foreign investment (IED) due to the fact that it represents a model that promotes the insertion in global chains of value to increase the exports, to generate new jobs, to obtain currencies, and the imports on raw materials and components (Carrillo, Hualde, \& Quintero, 2005; Contreras, Carrillo, \& Olea, 2012) Between 2003 and 2013, the annual rate growth of the IED was 7.36\% (SE, 2015). In 2013, according to SE, the IED increased to 735 million of dollars, superior to the amount of 2014 (SE, 2015), which was 511.4 million, and represented 2.2 of the amount received in Mexico.

The manufacturing industry was the main destination of the IED, received by the state in 2013. From a total IED, $85 \%$ are enterprises from the secondary sector (manufacturing), followed by commerce with 7.6 and the service of temporary accommodation and preparation of food and beverages with the $3.5 \%$ (SE, 2015). Tamaulipas obtained the $10^{\text {th }}$ place in 2013 among the states with better acquisition of IED, due to a group of technical and economic factors, such as geography, human resources, income level, etc (Flores Flores, et al., 2017). Tamaulipas got $6^{\text {th }}$ place in the country because of the number of businesses (420 enterprises) that represented $6.7 \%$ of the total. The main part of the enterprises of this type are foreign (INEGI, 2015).

All this could be explained in part by the mining and oiling specialization in the state, and by the importance that IED has granted to the state particularly as assembly factories, which are settled mainly in the northern border, Matamoros, Reynosa and Nuevo Laredo had benefited from their geography, because they are referents in the country for the IED located in their territories. Above all, Reynosa gathers several clusters of assembly enterprises in various sectors, such as clothing manufacturing and car pieces from the automobile industry, among others.

In this context, the objective of this work is to determine the type of bonds that are established by the assembly enterprises in the electric electronic sector in Mexico, through a case study and applying a specific methodology (Marin \& Giuliani, 2006), that allows us to measure how the related enterprises in Transnational foreign enterprises (EET) with productive and nonproductive local agents.

The research questions that guide this investigation are: 
- Which are the bonds established the assembly enterprises selected in the study with local agents?

- How are they classified and represented following the methodology of Marin and Giuliani (2006) using the Netdraw software?

For this, a theoretical discussion is presented about the bonds of the related enterprises with local agents and the role of the technological involvement. After that, a case study methodology is presented and supported by the election of the enterprises involved in the study. In the following part, information and results are analyzed which will allow to classify the enterprises according to the bonds established with the local and foreign agents, following the methodology of Marin and Giuliani (2006). Lastly, the conclusions are presented.

\section{Bonds, IED, and Knowledge Contributions}

Since the 80'san extensive debate has taken place in the assembly enterprise, in the economic growth, and the development of the territories where they are established. There is an optimistic position that considers that assembly enterprises are part of this productive model that has contributed to transform a part of Mexico, generating jobs with salaries that have increased meanwhile the enterprises have evolved technologically (Carrillo \& Lara, 2004; Carrillo \& Gomis, 2005, 2011). The other position, more critical and pessimistic, it considers that the assembly enterprises have a limited effect over the economic development in the territories where they are located, and if they have impacted in the job offers, this will be low quality and with a lower income (De la Garza, 2015, Bendesky et al., 2004).

Some authors recognize the fast success in the program in the creation of jobs in the northern border of the country (Ayer \& Layton, 1974; Brooke \& Peach, 1981). IN particular, Calderon and Mendoza (2000) have studied that the first explaining factor of the manufacturing job expansion in the north of Mexico, in particular for the states of Baja California Norte, Chihuahua, and Tamaulipas, it was the growth in the manufacturing jobs in the border. Between 1993 and 2000, the manufacturing job in the border had grown to an annual rate of 5.8\%. The states that generated the most jobs in the period were Chihuahua, $10.9 \%$, Baja California Norte, 9.2\%, Tamaulipas, 8.6\%, and Coahuila 5.9\% (Fullerton, Vázquez, \& Barraza, 2011).

The foreign transnational enterprise (EET) through IED could contribute to the economic development mainly through two channels. One, facilitating the productivity growth and the exports and creating jobs. This group of effects generates additional incomes that increase the capacity of expenses in consumption and investment, and because of that, economic growth. Two, through the creation of technological involvement and knowledge contributions (Spillover). Precisely, this second channel is the one we will discuss in this work (Dutrenit \& Vera Cruz, 2004).

The contribution effects, understood as the transference of knowledge to enterprises or institutions of the territory, they depend on the bonds or the type of relationships established by IED, in particular, the foreign transnational enterprises (EET) in the destination country with the enterprises and the local agents.

The EET and their capacity of generating contribution effects require the existence of at least two requisites, or fundamental conditions for them to appear (Dutrenit \& Vera Cruz, 2004):

1). Since the offer's side or knowledge production (related to EET) (Demanding bonds). From the existence of a corporative strategy belonging to EET prone to facilitate or promote the collaborative relationships with agents or local enterprises, that grant a sufficient autonomy to the related enterprises to develop a technologic and innovative behavior, also the industry's intensity where the enterprise is located. These autonomous behaviors always depend on the objectives of corporative strategies According to Altenburg (2000), the strategies respond to the search of markets, resources, efficiency, strategic resources, or capacities. Thus, the related enterprises of EET always respond to a specific corporative strategy and depending on that, the related enterprises could develop more collaborative bonds in the sense of facilitating knowledge flows to the local enterprises. However, the capacity of developing this type of productive bonds could not happen, if the local enterprises are not prepared for that.

2). From the side of the acquisition or knowledge demand (local enterprise) (bonds' offer). The existence of technological capacities in the local PYME to cover the necessities of supplies, in the quality of standards of their products at an international level, in the update of their productive and management practice, teaching practice for their human resources, among other factors. The technological capacities are according to Kim (1997): “...the ability to make an effective use of the technological knowledge to assimilate, use, adapt, and change the existent technologies. It also allows to create new technologies and develop new products and processes in response to the changing economic environment..." In other words, to have the option to develop bonds that make possible the generation of contributions, this will depend on the existence of technological capacities belonging to them. Frequently, local enterprises don't have productive capacities sufficiently developed to supply an amount of 
materials or services with the required quality by the EET (Dussel, 2001). The development of appropriate technological capacities means to advance in accumulating processes, and technological development, since stages in which simple routine operations are performed to others which are more complex (Dahlman \& Westphal, 1982; Lall, 1992; Bell \& Pavit, 1995), which require innovation, and learning.

A type of specific technological capacity that the local enterprises have the need to promote to develop effective and long term bonds is their absorbing capacity. This means, the capacity that they have to absorb the external available knowledge and sum it up to their routines and productive processes. The absorbing capacity depend on the base of the available knowledge in the organization, that grants the ability of identifying new information, assimilate it, and add it to the routines of the organization, and the intensity of the efforts, which is related to the internal organizational mechanisms oriented to develop this capacity.

\section{Methodology}

For the measurement of the bonds of the enterprises subjected to the study and the local agents, a methodology was developed by Marin and Giuliani (2006), in a study about multinational enterprises in Argentina. In that document the bonds of the subsidiary companies are evaluated, and also the spillovers effects (Annex 1).

In this research, case study was used due to the fact that this method when it examines the phenomena of its real context, takes advantage of the richness of their content and it describes the context where the phenomena is being studied (Eisenhardt and Graebner, 2007). Following Yin (1989) proposal, the comparison of the differences among the cases subjected to research was adapted, to obtain results that could explain the situation of the components of the subject study, which in this research are the factors that explain the nature of the local and international bonds. The research has a multiple exploring, descriptive, and explanatory goal about the types of bonds of established knowledge. For doing this, the main objective of our research, and following Yin (1989), about one of the purposes that the research may have, is to validate the studies of Marin and Giuliani (2006). In our research, some cases that offered a major chance of learning were selected (Stake, 1994) and that they could allow an analytical generalization (not statistic) from the results (Ragin \& Becker, 1992; Easton, 1994).

The index (dependent variable) intensity of the bonds of knowledge in assembly enterprises subjected to the study with local and international agents is the result of the multiplying of two variables (A and B). Variable A is obtained from the answers about the meaningfulness of the knowledge sources - headquarters, subsidiary, internal sources, suppliers, competitors, educational institutions, the government, in this order of importance for the evaluated enterprises (irrelevant 1 to very relevant 4, in a Likert scale). Variable B establishes the number of bonds, whether they are national or international, as it is indicated in the tables of the enterprises.

Table 1. Types of knowledge bonds from the subsidiary enterprises from the EMN

\begin{tabular}{|c|c|}
\hline Type of bond & Characteristics \\
\hline $\begin{array}{l}\text { Globally } \\
\text { diversified } \\
\text { (GDiv) }\end{array}$ & $\begin{array}{l}\text { They are subsidiaries that have strong bonds with their headquarters and enterprises from the corporation, but they have } \\
\text { made links with international corporations, and also with local agents. The GDiv could be associated with strong } \\
\text { capacities of innovation. Due to the model of entrepreneurism designed by the managers, it is likely that the GDiv search } \\
\text { to exploit any source of knowledge or the resources in their close geography. This is the reason why this type if subsidiary } \\
\text { is prone to create local bonds with territory agents, and because of that, to generate positive spillovers. }\end{array}$ \\
\hline $\begin{array}{l}\text { Globally } \\
\text { dependent } \\
\text { (GDep) }\end{array}$ & $\begin{array}{l}\text { They are the subsidiaries that only bond with their headquarters, and with enterprises from the corporation. They are } \\
\text { characterized by strong bonds with the headquarters, and with other enterprises from the corporate group, they have from } \\
\text { medium to strong resources of generation of knowledge like the capacity of innovation, but with limited local bonds in } \\
\text { the country of origin. This type of subsidiaries could potentially generate spillovers in the country because of their } \\
\text { privileged access to the knowledge of the headquarters, but they fail to do so, because of the organizational model that } \\
\text { inhibits the formation of local bonds of knowledge. }\end{array}$ \\
\hline $\begin{array}{l}\text { Globally } \\
\text { independent } \\
\text { (GInd) }\end{array}$ & $\begin{array}{l}\text { They are the subsidiaries that have not established bonds with the headquarters, and with enterprises belonging to the } \\
\text { corporation, but only with other agents outside their own multinational group. They are characterized by the development } \\
\text { of bonds with other agents in the international markets that are independent from the corporation, from moderately to } \\
\text { highly strong resources and innovation capacities, and intense local bonds. These local bonds could be because of } \\
\text { entrepreneurism and dynamic behavior from this type of subsidiary, which makes them to actively search collaboration of } \\
\text { international agents, and also in the local area. . }\end{array}$ \\
\hline $\begin{array}{l}\text { Globally } \\
\text { isolated } \\
\text { (GIso) }\end{array}$ & $\begin{array}{l}\text { They are subsidiary enterprises that have scarce bonds with the central corporation, or with any other international } \\
\text { company, and also with local agents. They do not establish international bonds, they have a weak capacity in generating } \\
\text { knowledge and innovation capacities, and have created local links. These subsidiaries with a Little innovation capacity } \\
\text { don't have a lot to transmit in their countries because they are not able to generate knowledge that could be assessed, or } \\
\text { because they have absorption capabilities. }\end{array}$ \\
\hline
\end{tabular}

Source: Marin and Giuliani (2006). 
The analysis unit of our work is formed by five assembly subsidiary enterprises selected in the electric electronic sector in Tamaulipas state. The cases were selected among a sample by convenience of 25 enterprises based on the criteria of enough information to maximize the process of investigation (Garcia et al, 2012). As a result, the information obtained from the five enterprises must allow maximizing the results in terms of quality and amplitude. The enterprises subjected to study are organizations with an important generation of jobs, and where the absorbing of knowledge offers information for its study in depth (Flybjerg, 2006).

Taking into account the gathered information through interviews with managers, and engineers, department managers of engineering, development and quality, it was built a database that includes the information about relevant and irrelevant aspects about innovation topics, and also about the collaboration with foreign and local agents.

The information was classified according to the proposition of Marin and Giuliani (2006) (Table 1). The results were framed with the program Netdraw, which allowed to identify and represent the relationships that the studied enterprises have established with the local and foreign agents as a source of information or destination of the transferred knowledge, in case that this had happened. In the study, Netdraw represents the bonds, measured by the amounts of interactions that the enterprises have had with national and foreign agents, headquarters, local suppliers, universities, etc.

\section{Results}

In the following text, I will present the results obtained from the measurement of the local and international bonds of the enterprises subjected to study.

\subsection{Clasification and Representation of the Bonds by Assembly Enterprise}

\section{Assembly enterprise (A)}

It is a manufacturer of electronic components and it focuses in looking for technological solutions to customers' problems. The history of the enterprise began in 1919 in the established laboratories to buy an investigation company in Cleveland, Ohio, that had invented a high temperature alloy. After this, they widened their list of products, and they were imrpoving their products and processes, taking advantage of the new technologies (Table 2)

Table 2. Assembly enterprise description

\begin{tabular}{ll}
\hline Characteristic & General description \\
\hline Headquarters & United States \\
Beginning & 1999 \\
Size & Big (1300) \\
Sector & Manufacturing \\
Product & Capacitors de tantalic (chips) \\
Sub product & Manufacturing of accessories, electric devices, and electric generation equipment. \\
\hline
\end{tabular}

Source: Self ellaboration from the interviews.

\section{Types and intensity from the local bonds}

The assembly enterprises don't have bonds with the Federal or State Government outside the program of the Exporting Assembly Mexican Industry (IMMEX). The government is considered as a passive agent inside their innovation and growth programs. They have only received supportfrom the Federal Comission of Electricity (CFE) to help to pay the cost of electric energy.

Their bonds with the educational sector are given by the making of professional practice with students in professional education, and joined projects of investigation with a local educational center, where the enterprise proposes the school what to investigate, or which area needs support. There's not any proactivity planned by the educational institutions to approach the assembly enterprise.

It highlights that the main obstacles to achieve a bond with the educational sector are that professors are not updated, and also the lack ot innovations and technologies, the failures in the infrastructure inside the educative areas to be updated. There is no bond with enterprising associations or commerce institutions. (Figure 1). 


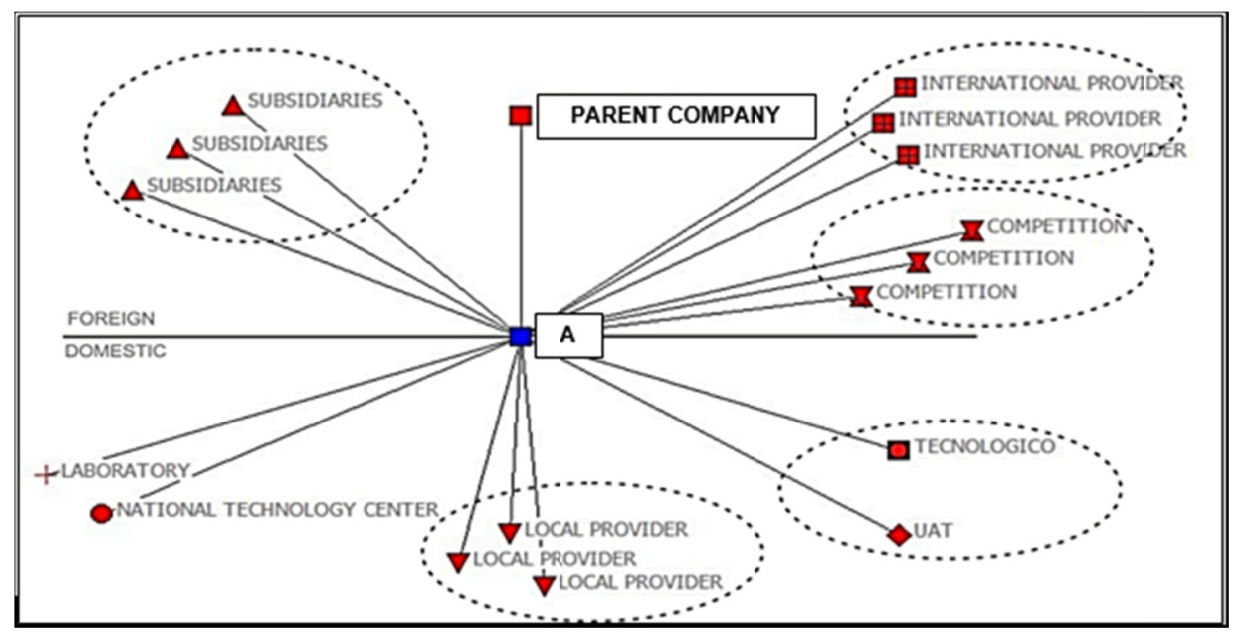

Figure 1. Assembly enterprise's bonds

Source: Self elaboration.

The results show that the assembly Enterprise A is found among the globally diversified (Gdiv) enterprises with a value of 19.68 in a 0 to 24 scale due to the integration in the international market, that is actively made through the central corporation, and with the knowledge bonds that have been established with foreign enterprises and some educational centers in the same country (table 3).

Table 3. Summary of the assembly enterprise A

\begin{tabular}{lll}
\hline Globally diversified (Gdiv) & Index of the bond & Variable \\
\hline Internal and external sources of knowledge & 3.28 & $\mathrm{~A}$ \\
International and local bonds & 6 & $\mathrm{~B}$ \\
Variable A * Variable B & 19.68 & \\
\hline
\end{tabular}

Source: Self elaboration.

They have an ample network of knowledge, being in the world market with companies in China, United States and Europe. They show a high degree of integration in the joined development of products, and the investigation with other factories of the same type of the assembly enterprise (A). It should be highlighted that the passive role of the government for getting the innovative capacities of the enterprise to outside the country is compensated with the integrating educational politics actions in teaching centers that look for professional practice, scholarships, etc. In the enterprise.

Lastly, the assembly enterprise (A), which is a chip producer has been characterized by the patent development which were registered in United States as part of the corporation's strategy to decrease the costs by increasing the quality of the product and the efficient delivery of it; to make improvements in all the stages of the productive process, such as, racking system (production system), and the applying of innovations aimed to reduce the costs in raw materials and optimizing the resources, allowing innovation in their products.

\section{Assembly Enterprise (B)}

The assembly Enterprise B is part of a company that was installed in Mexico in 1996. It has an extensive line of products and services provided to many industries and customers around the world. The company offers electrification services, offering services and products of energy wit charcoal, oil, natural gas, nuclear energy, water and air technologies, which can offer solid productivity returns and meaningful environmental benefits. (Table 4) 
Table 4. Description of the assembly enterprise B

\begin{tabular}{ll}
\hline Characteristic & General description \\
\hline Headquarters & United States \\
Beginning & 1996 \\
Size & Big (525 employees) \\
Sector & Manufacturing \\
Product & Current generation \\
Sub product & Manufacturing of accessories, electric devices, and electrical energy generation. \\
\hline Source: Self elaboration. &
\end{tabular}

\section{Types and intensity of the local bonds}

This enterprise is not linked to the entrepreneurial sector, but because of the purchase of office or cleaning supplies, and there's no bond that takes this enterprise to the creation of knowledge.

Long term suppliers are generally foreign, and local suppliers only do it in the short term, and for emergency situations.

The bonds with the headquarters are given a great importance, and also the subsidiaries and other internal sources, in the same way to suppliers and competitors. Furthermore, the educational institutions play an important role for the creation of knowledge. They have bonds with universities, and foreign technological centers. (Figure 2).

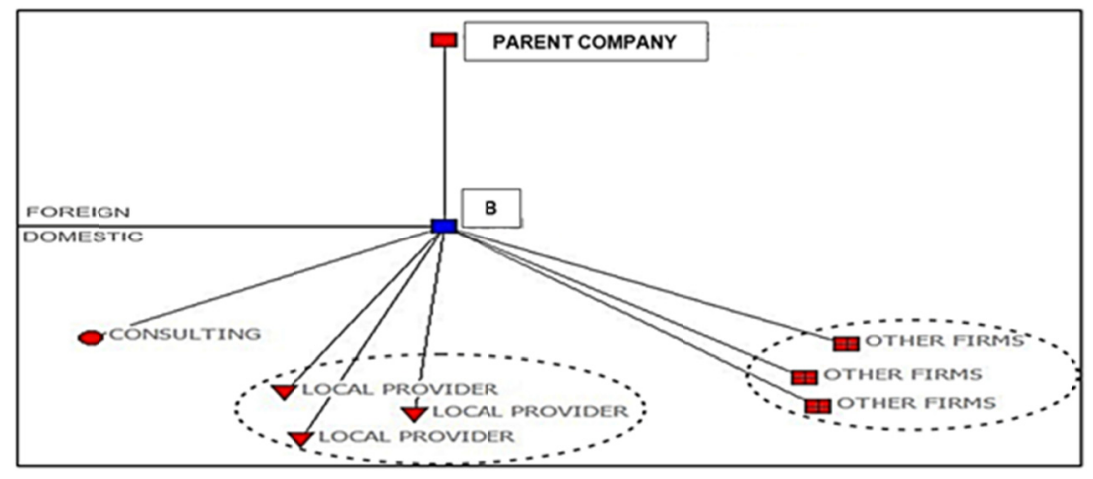

Figure 2. Bonds with assembly enterprise B

Source: Self elaboration

This enterprise has characteristics that can place it inside the globally diversified (Gdiv) (Marin and Giuliani, 2006). The obtained result is the factor 16.26 in a scale from 0 to 24 which does not indicate that it is an enterprise highly bonded with knowledge international and local sources. They say they have bonds with educational institutions but only for the development of professional B.A practices, and not like research projects. (Table 5).

Table 5. Summary of assembly enterprise's bonds

\begin{tabular}{lll}
\hline Globally diversified (Gdiv) & Index of the bond & Variable \\
\hline Internal and external knowledge sources & 2.71 & $\mathrm{~A}$ \\
Local and international bonds & 6 & $\mathrm{~B}$ \\
Variable A * Variable B & 16.26 & \\
\hline
\end{tabular}

Source: Self elaboration.

\section{Assembly enterprise (C)}

This is an assembly enterprise placed in Matamoros, Tamaulipas, and dedicated to offer designing services, as mechanical design, Full 3-D modeling and simulation, termal analysis, and simulation, electrical design, cable 
and harnesses design, and the modeling of plastic components, components design, sub-assembly, and high level assembly testing, among others (Table 6).

Table 6. Description of assembly enterprise C

\begin{tabular}{ll}
\hline Characteristic & General description \\
\hline Headquarters & Scotland \\
Beginning & 2005 \\
Size & Big $(285$ employees $)$ \\
Sector & Manufacturing \\
Product & Electrical pieces, electronic components, electronic pieces and \\
& equipment. \\
Sub product & Accessories manufacturing, electrical devices, and generation of \\
\hline
\end{tabular}

Source: Self elaboration

\section{Types and intensity from the local bonds}

The main bonds with the educational sector are exclusively useful for the reception of students in professional practices and visits. No joined projects are made together. They mention they haven't received support from the governments, whether city or state government, or from educational institutions for the innovation of their products. There is no relationship with the local suppliers, but for the purchase of consumption articles not related with the production.

In this assembly enterprise we can observe the characteristics of a business unit dependent of the corporation of headquarters which is not able to innovate or make decisions, it is also completely isolated from its environment (few bonds) because there are not joined research projects with universities, or with government agents for the innovation. (Figure 3).

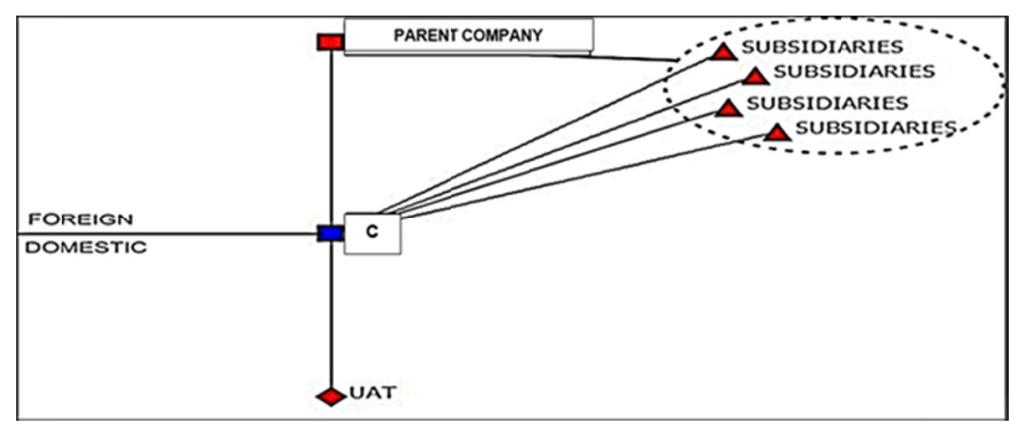

Figure 3. Bonds of assembly enterprise C

Source: Self elaboration.

All this takes us to conclude that the assembly enterprise $\mathrm{C}$ has the profile to be placed inside the classification of globally dependent (Gdep), according to Marin and Giuliani (2006). A value of 5.7 on a scale of 0 to 24, which indicates that company $\mathrm{C}$ is highly dependent on the headquarters, exclusively, without relations with other agents. (Table 7).

Table 7. Summary of the bonds of assembly enterprise C

\begin{tabular}{lll}
\hline Globally dependent (Gdep) & Index of the bond & Variable \\
\hline External knowledge sources & 2.85 & $\mathrm{~A}$ \\
Local bonds & 2 & $\mathrm{~B}$ \\
Variable A * Variable B & 5.7 & \\
\hline
\end{tabular}

Source: Self elaboration. 
The assembly enterprise $C$, which produces electrical parts and components, it increased $50 \%$ in 2010 (related to 2006) the improvements in their products, that in the average have a result of 43 a year. The use of information technologies have been used as a strategic organizational competitive tool for achieving a better costumer's satisfaction, because through this it's possible to know the requirements of the design of the product, and also to give a following along the project or product in particular.

\section{Assembly enterprise D}

The assembly enterprise D had its origin in Texas in 1971, where a bilateral cable central was placed, it was a study center of Computer's science, video information and gathered data. In June of 1972 was established in the city of Matamoros, Tamaulipas, beginning a new cycle after September, 1981, where 1700 employees with engineering functions, manufacturing, and its service of lines of production are currently working. It offers, beside products and components of cable for television and radio. (Table 8)

Table 8. Description of the assembly enterprise D

\begin{tabular}{ll}
\hline Characteristic & General description \\
\hline Headquarters & United States \\
Beginning & 1981 \\
Size & Big (1 7000 employees) \\
Sector & Manufacturing \\
Product & Components for television and radio cables \\
& (bilateral converter) \\
Sub product & Manufacturing of accessories, electrical devices, and electrical energy generation equipment \\
\hline
\end{tabular}

Source: Self elaboration.

\section{Types and Intensity from the Local Bonds}

The assembly enterprise D has bonds with educational sector institutions, but these relationships are not important for the innovation of the same enterprise. Some of these agents with the ones is bonded are: the universities, technological centers, laboratories and the technological institute. The bonds of this enterprise in the local area are with customers for the acquisition of consumer goods, and not raw materials, or suppliers of intermediate goods.

For the previously exposed data and for its isolation, we can place the assembly enterprise $\mathrm{C}$ according to the classification of Marin and Giuliani (2006) as Globally Isolated (Giso), because it has the characteristics of these enterprises, but above all, because in spite of having obtained a value of 3.7 in a scale from 0 to 24 (table 9), the enterprise has shown a weak knowledge generation capacity, and it has a scarce capacity of generating any kind of information that can be transferred to other agents.

Table 9. Summary of the bonds of the assembly enterprise D

\begin{tabular}{lll}
\hline Globally Isolated (Giso) & Index of the bond & Variable \\
\hline Internal knowledge sources & 1.85 & $\mathrm{~A}$ \\
Local bonds & 2 & $\mathrm{~B}$ \\
Variable A * Variable B & 3.7 & \\
\hline
\end{tabular}

Source: Self elaboration.

As it was said before, the enterprise showed a very scarce capacity of knowledge generation, and it is scarce because of the capacity for generating any type of information that can be transferred to any agent (figure 4) 


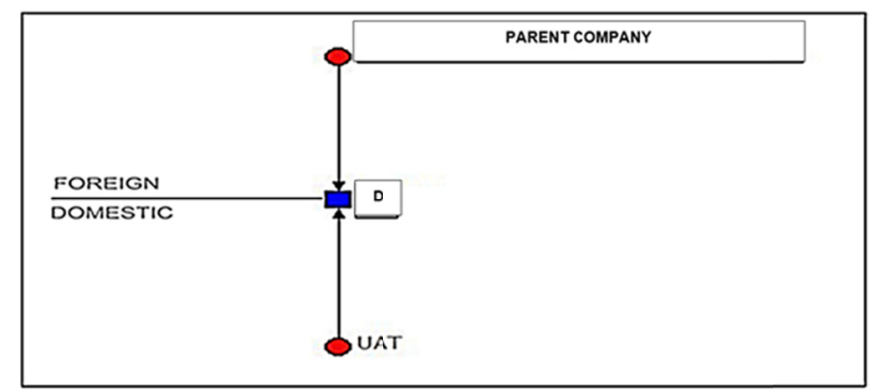

Figure 4. Bonds of assembly enterprise D

Source: Self elaboration

\section{Assembly Enterprise E}

This assembly enterprise manufactures radios for vehicle use, which improvements to its products have an average of 24 a year in the period from 2006 to 2010. As part of the innovative process, this enterprise incorporated the Investigation and Development departments, Design, Quality Control, and Engineering to develop radios for cars. (Table 10)

Table 10. Description of assembly enterprise $E$

\begin{tabular}{ll}
\hline Characteristic & General description \\
\hline Headquarters & United States \\
Beginning & 1996 \\
Size & Big (525 employees) \\
Sector & Manufacturing \\
Product & Current generators \\
Sub product & Accessories manufacturing, electricals devices and electrical energy \\
\hline
\end{tabular}

Source: Self elaboration from the interviews.

\section{Types and intensity of the local bonds}

Taking in consideration what we have said before, the assembly enterprise E follows the classification of Marin and Giuliani (2006) as Globally independent (Gind), because it shows a high capacity to establish global bonds and a high degree of independence from the headquarters (table 11).

Table 11. Summary of the bonds of the assembly enterprise $\mathrm{E}$

\begin{tabular}{lll}
\hline Globally independent (Gind) & Index of the bond & Variable \\
\hline Internal knowledge sources & 2.28 & $\mathrm{~A}$ \\
Local bonds & 5 & $\mathrm{~B}$ \\
Variable A * Variable B & 11.4 & \\
\hline
\end{tabular}

Source: Self elaboration.

This is observed in the constant search for the local bonds, which supports the decision to group it as Globally independent (Gind). A value of 11.4 was obtained in the measurement of its bonds in the scale of 0 to 24, which justifies the classification of the assembly enterprise $E$ in the category of Globally independent (Gind) (annex 1).

The bonds with the teaching centers are meant to receive students in their professional practices.

Apparently, the match marking policies have not been relevant; neither do the ones of financial assistance, but only in exportation and sales movements. They have supported local suppliers by granting those credits and signing long term agreements, and they achieve a cooperation of technological development with customers. 
As it was mentioned before, the assembly enterprise $\mathrm{E}$ manufactures radios for vehicle use, their improvements to their products have an average of 24 by year in the period of 2006 to 2010 . Their products are adapted to the necessary requirements asked by the customers (figure 5).

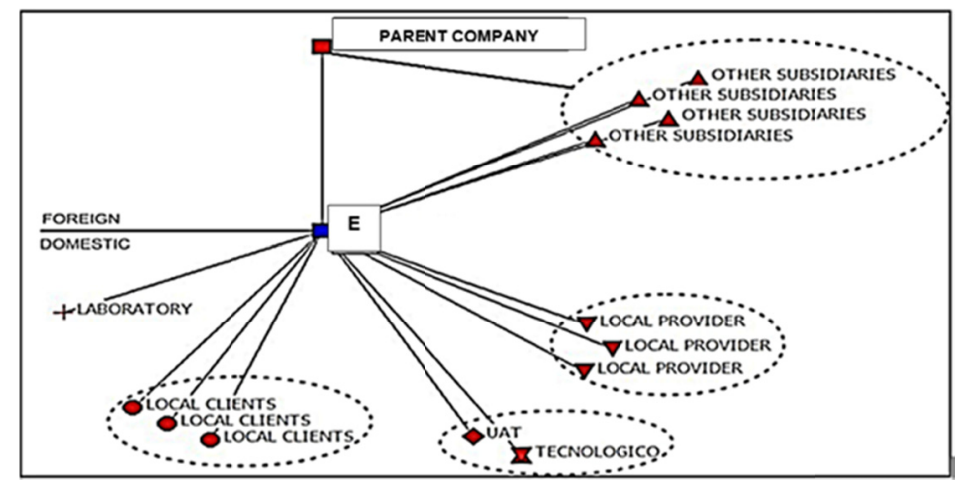

Figure 5. Bonds of the assembly enterprise $\mathrm{E}$

Source: Self elaboration.

\section{Analysis integration}

The bonds represent the real effort of the enterprise to establish a linking contact with a determinate agent, by which the variable is built from multiplying the importance that the enterprise grants the bonds with the agent by the existence or lack of a bonding agreement with itself.

The importance that the enterprise gives to the bonds of the agent was measured in the applied survey with a Likert scale of 4 points, meanwhile the existence or absence of a bonding agreement with the agent is measured by an item that takes a value of 1 if there is an agreements, and 0 if there is no such agreement. Because of this, the maximum value that this variable could take is 4 points, with the exception of an effective bonding with educational institutions, because they group four organisms (universities, laboratories, technological institutes, and technological centers), being able to take a maximum value of 16 points (table 12).

Table 12. Effective bonding of the interviewed enterprises

\begin{tabular}{llllll}
\hline Enterprises & & & & & \\
\hline & $(C)$ & (D) & (B) & (A) & (E) \\
\hline V.E. Headquarters & 4 & 2 & 4 & 4 & 2 \\
V.E. Subsidiaries & 4 & 0 & 4 & 4 & 0 \\
V.E. External consulting & 4 & 0 & 3 & 4 & 0 \\
V.E. Suppliers & 0 & 2 & 3 & 4 & 3 \\
V.E. Competitors & 0 & 0 & 2 & 0 & 0 \\
V.E. Educational institutions & 1 & 1 & 8 & 8 & 6 \\
V.E. Government & 0 & 0 & 0 & 0 & 0 \\
\hline
\end{tabular}

Source: Self elaboration.

According to the bonds of the enterprises with its internal chain, it is observed that the electronic electrical sector organizations have a strong bond with their headquarters and their subsidiaries or belonging to a superior logistic chain.

Analyzing the organizations individually, (figure 6) shows assembly enterprise $\mathrm{C}$ with effective bonds of $100 \%$ in its internal chain and catalogued inside the classification of Globally dependent, being presented at the same time, the same situation for the assembly enterprises A and B, which were placed inside the Globally diversified classification. 


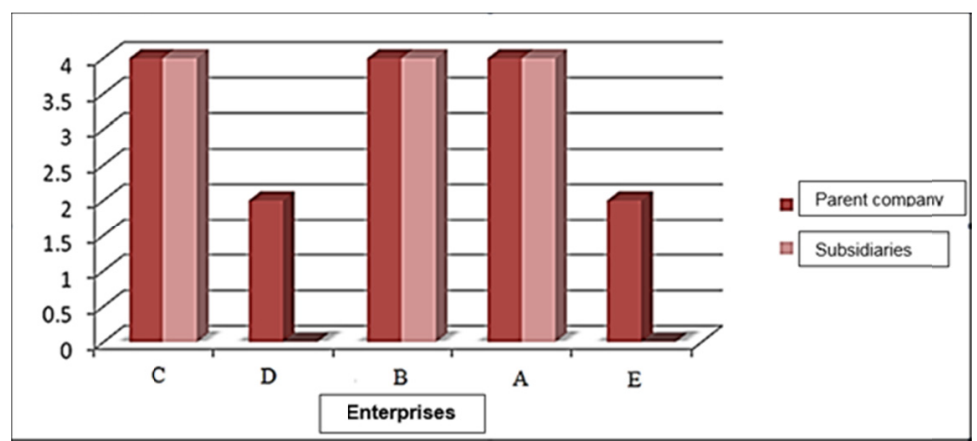

Figure 6. Bonds with the internal organizational chain

Source: Self elaboration.

In the case of the assembly enterprise $\mathrm{D}$, which can be found in the classification of globally isolated, and the assembly enterprise E, in globally independent, the results are different, because they present $25 \%$ effective bonds. They just keep a weak bond with its headquarters, and a null relationship with the other subsidiaries belonging to the headquarters, so, in this sense, we can say that there is a punctual and fragmentary integration with its supply chain. Meanwhile in the assembly enterprises C, a, and B there is a systemic integration that could be translated in favorable conditions for the absorption and generation of innovations in such places.

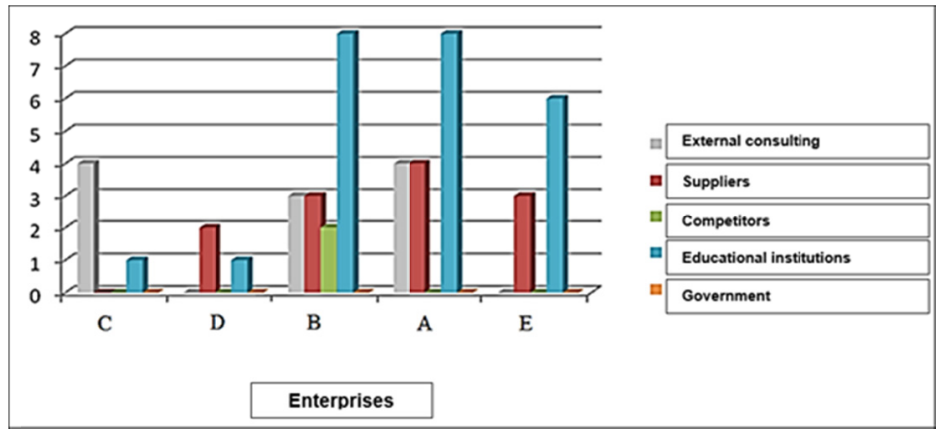

Figure 7. External organizational bonds

Source: Self elaboration.

According to the bonding with suppliers, the results indicate some effective high bonds, in $60 \%$, which demonstrates a potential chaining that shows up an adequate logistics at the level of demand from the assembly enterprises in the same field. In particular, assembly enterprise A has $100 \%$ of effective bonds against $75 \%$ shown by the assembly enterprises B and E. Meanwhile, assembly enterprise D shows some effective bonds at $50 \%$, and assembly enterprise $\mathrm{C}$ shows a lack of chaining back, not having any effective bond.

In other way, and as an important element in the analysis inside the value chain, it is observed the existence of a practically null relationship with the competitors, showing a lack of strategic alliances that favor a high level growth in the sector and the region.

About the educational sector bonds, even when the enterprises consider this element as important, the effective bonds are very weak, only at a level of $30 \%$. This has been studied by diverse researchers, and it reflects by one side that the technologic assistance of the educational institutions is not adequate, besides, it involves complex administration procedures, which complicates the linking, meanwhile, other reason is that the potential demand of the enterprises, it has a very specific profile that many official institutions are not in conditions to offer. (Yoguel et al., 1998)

\section{Conclusions}

These results support a scientific perspective about the existence of a limited knowledge transference capacity from universities to enterprises. In most of the Latin American countries, the educational institutions have few bonding possibilities, reaching a first stage, in which they are given support to the university research, or a 
collaborative research is produced, without consolidating the transference of high technologies (OCDE, 2010).

About the effective bonds with the public or government sector, an almost inexistent relationship could be observed, there, the productive sector organizations do not consider the Estate work important in the support of the bonding. In no enterprise was observed that there was any type of bond with this sector.

This lack of bonds is worrying, considering that according to the triple helix theory, the government plays an important role, and bond for the development of the society of knowledge (Etzkowitz, 2002), the government has the task of facilitating the relationship enterprise - university, with an active participation through legislation, instruments and fiscal incentives appropriate for the increase and dynamism with such relationships (Chang, 2010). In this sense, the lack of relationship could influence in the weak relationship of the enterprises with the university.

In attention to the relationships enterprise, government and university could be considered to exist a separation of the institutional spheres, and the relationships among them. This is, administration barriers could be observed, or some others, referent to the public politics that make the bond of the industry more difficult. This ends up affecting the introduction of regional technological innovations.

The situation of the bonds of limited knowledge, and reduced capacity of knowledge transference to the entrepreneurial organizations in Latin America and Mexico, it forces the governments design specific politics, so the enterprises play a fundamental role in the knowledge economy, developing their absorption capacity (Cohen, W.M \& Levinthal, D.A. 1990) as a generating source of proper knowledge.

One of the programs that has been promoted the most is the development of a network of local suppliers, even though the results are still limited in Mexico and in the northern border of Tamaulipas, they are particularly scarce, or completely inexistent. As Isaac and Quintana (2013) claim, These programs, local or federal must be guided to form networks of enterprises of a small scale in those sectors of major regional potential, and where the governing of the process of production must be kept. This type of politics of technological development, and innovation also promotes the improvement of technological capacities in the local enterprises, and not only in the sectors of high technology, but also in traditional or agriculture industrial sector, as it is the case of the wine industry and the "catching up" successful process in Argentina and Chile (Giuliani, et al, 2011). As a result, it strengthens the local technological capacity, it is necessary to reinforce the base of knowledge of the enterprises, and this necessarily occurs for supporting the professional university education (Isaac, et al, 2013)

\section{References}

Altenburg, T. (2000) Linkages and Spill-overs between Transnational Corporations and Small and Medium-Sized Enterprises in Developing Countries - Opportunities and Policies, Reports and Working Papers, German Development Institute. https://www.files.ethz.ch/isn/28039/2000-05.pdf

Ayer, H., \& Layton, R. (1974). The Border Industry Program and the Impact of Expenditures on a U.S. Border Community, Annals of Regional Science, 8, $105-117$.

Bell, M., \& Pavitt, K. (1995). The development of technological capabilities. Trade, Technology and International Competitiveness, 22, $69-101$.

Bendesky, L., Garza, E., Melgoza, J., \& Salas, C. (2004). La industria maquiladora de exportación en México: $\begin{array}{llllll}\text { mitos, } & \text { realidades } & \text { y crisis. Estudios }\end{array}$ http://www.redalyc.org/articulo.oa?id=59806502

Brook, K., \& Peach, J. (1981). Income, Employment, and Population Growth in the U.S.-México Border Counties. Texas Business Review, 55, 136-140.

Calderón, C., \& Mendoza, J. (2000). Demanda regional de Trabajo en la industria maquiladora de exportación en los estados de la frontera norte. Frontera Norte, 12(24), 59-84.

Carrillo, J., \& Gomis, R. (2005). Generaciones de maquiladoras: Un primer acercamiento a su medición. Frontera Norte, 17(33), 25-51.

Carrillo, J., \& Gomis, R. (2011). Un estudio sobre prácticas de empleo en firmas multinacionales en México: Un primer mapeo. Frontera Norte, 23(46), 35-60.

Carrillo, J., \& Lara, A. (2004). Nuevas capacidades de coordinación centralizada. ¿Maquiladoras de cuarta generación en México? Estudios sociológicos, 66, 647-667. Retrieved from https://www.researchgate.net/publication/28136041_Nuevas_capacidades_de_coordinacion_centralizada Maquiladoras_de_cuarta_generacion_en_Mexico 
Carrillo, J.; Hualde, A., \& Quintero, C. (2005). Maquiladoras en México. Breve recorrido histórico. Comercio Exterior, 55 (1), 30-42.

Chang, H. G. (2010). El modelo de la triple hélice como un medio para la vinculación entre la universidad y empresa. Revista Nacional de Administración, 1(1), 85-94.

Cohen, W. M. \& Levinthal, D. A. (1990). Absorptive capacity: A new perspective on learning and innovation. $\begin{array}{llll}\text { Administrative } & \text { Sciences } & \text { Quarterly, } & \text { 569-596. }\end{array}$ http://www.jstor.org/stable/2393553?seq=1\#page_scan_tab_contents

Contreras, O.; Carrillo, J., \& Olea, M. J. (2012). Desprendimiento de las multinacionales, una vía para el aprendizaje y la innovación en empresas locales. En El Colegio de la Frontera Norte y Complejidad, Ciencia y Sociedad (Eds.), Dilemas de la innovación en México, dinámicas sectoriales, territoriales e institucionales, 301-336.

Dahlman, C. \& Westphal, L. (1982). Technological effort in industrial development. The economics of new technology in developing countries. London: Frances Pinter.

De la Garza, E. (2015). Neoliberalismo y diversidad de corporativismos. Cuadernos del CENDES, 32 (90), $35-62$.

Dussel Peters, E. (Coord.) (2001). Claroscuros: integración exitosa de las pequeñas y medianas empresas en México. CEPAL. http://repositorio.cepal.org/bitstream/handle/11362/1690/1/S338642D976_es.pdf

Dutrenit, G. y Vera - Cruz, A. (2004). La IED y las capacidades de innovación y desarrollo locales: lecciones del estudio de los casos de la maquila automotriz y electrónica en Ciudad Juárez. UN/CEPAL.

Easton, G. (1994). Methodology and industrial networks. En D. T. Wilson, \& K. Moller (Eds.). Relationships and networks: Theory and application. Kent: PWS.

Eisenhart, K. M. \& Graebner, M. E. (2007). Theory building from cases: Challenges and opportunities. Journal of Academy of Management, 50 (1), 25-32.

Etzkowitz, H. (2002). Incubation of incubators: Innovation as a triple helix of university-industry-government networks. Science and Public Policy, 29 (2), 115-128.

Flores, A. J. F., Herrera, M. Á., \& García Fernández, F. (2017). Factores determinantes de la localización del sector eléctrico-electrónico en México. Nóesis. Revista de Ciencias Sociales y Humanidades, 26 (51), 20-44. http://erevistas.uacj.mx/ojs/index.php/noesis/article/viewFile/733/pdf 5

Flyvbjerg, B. (2006). Five misunderstandings about case study research. Qualitative Inquiry, 12 (2), 219-245. http://flyvbjerg.plan.aau.dk/Publications2006/0604FIVEMISPUBL2006.pdf

Fullerton Jr. T. M.; Vazquez Morales, J. C. \& Barraza de Anda, M. P. (2011). Dinámica de corto plazo del empleo en las maquiladoras de Reynosa, Tamaulipas. Ensayos Revista de Economía, 30 (1), 23 - 40.

García Fernández, F., Sánchez, M. \& Sevilla, J. A. (2012). Absorptive capacities of local enterprises from the lectric-electronics sector in the state of Tamaulipas, México. Journal of Technology Management \& Innovation. http://www.jotmi.org/index.php/GT/issue/view/jotmi25/showToc

Giuliani, E., Morrison, A. \& Rabelloti, R. (2011). Innovation and technological catch up: The changing geography of wine production. Reino Unido: Edward Elgar.

Isaac, J. \& Quintana, L. (2013). La estrategia de desarrollo para el Sur Pacífico de México. En Desigualdad y desarrollo regional. Chiapas y el Sur Pacífico mexicano. México: Plaza y Valdés.

Kim, L. (1997). Imitation to innovation: The dynamics of Korea's technological learning. Boston, MA: Harvard Business School Press.

Lall, S. (1992). Technological capabilities and industrialization. World development, 20 (2), 165-186.

Marin, A. \& Giuliani, E. (2006). Global and local knowledge linkages: The case of MNE subsidiaries in Argentina. SPRU Electronic Working Paper Series, No. 155, University of Sussex, SPRU - Science and Technology Policy Research.

OCDE. (2010, 17 de diciembre). Acuerdo de cooperación México - OCDE para mejorar la calidad de la educación de las escuelas mexicanas. Establecimiento de un marco para la evaluación e incentivos docentes: consideraciones para México. http://www.oecd.org/dataoecd/44/49/46216786.pdf

Ragin, C. C. \& Becker, H. S. (Eds.). (1992). What is a case? Exploring the foundations of social inquiry. 
Cambridge University Press.

Stake, R. E. (1994). Case studies. En N. K. Denzin, \& Lincoln, Y. S. (Eds.). Handbook of Qualitative Researh. Thousand Oaks, CA: Sage Publications.

Yin, R. K. (1989). Case study research, design and methods. Beverly Hills: Sage.

Yoguel, G. (1998). Desarrollo del proceso de aprendizaje de las firmas; los espacios locales y las tramas productivas. Instituto de Industria, Universidad Nacional de General Sarmiento (versión preliminar).

Annex 1. Determination of the bond indexes for the classification according to table 1 (Classification of Marín and Giuliani, 2006).

Each one of the enterprises that took part in the study is evaluated according to its international integration degree, and also by its bonds with local agents, using the previously presented methodology. The following survey was applied trying to satisfy the particular objectives.

With these questions, indexes of intensity in the innovation bonds of the enterprises with local and international agents were created.

Question 1. It was asked about the importance of alternative sources of information for innovation, In order of importance for the enterprises, some possible answers were: headquarters, subsidiaries, internal sources, suppliers, competitors, educational institutions, government. After this, it was asked to quantify the importance of these sources from irrelevant (1) to very relevant (4) (variable A).

Question 2. It was asked about the existence of knowledge interactions with other agents.

a. It was asked if they use the interactions with universities, technological centers, laboratories, technological institutes, suppliers, customers, headquarters, other subsidiaries, other companies outside the sector, consultants, and public agencies, and to what extent they are well used by the enterprise.

b. B. To respond where these bonds were offered, the possible answers were: local, regional, national, Latin America, Europe, USA, Canada, Asia, and others.

Based on these two questions two indexes related with innovation are produced: the first index looks for getting different intensity, and the types of global bonds; the second also, but focusing in the local bonds.

Index of international bonds

It combines the information of questions 1 and 2.

First. Question (1) is classified since: irrelevant 1, to very relevant 4 (variable A).

Second. The sources that don't come from an external international source are eliminated, sinde regional, USA, Canada, etc. (local is removed).

.Finally, the variable of global bonds is generated, product of multiplying variable $\mathrm{A}$ (number of international sources) by variable B (importance with a maximum of $24,0-4 * 6=24$.

After this, it is classified according with the obtained results.

1. There are no international bonds $=0$

2. Bonds with headquarters $=<0>6$

3. Bonds with headquarters and subsidiaries of the headquarters $=>6<12$

4. Bonds with other companies, but without headquarters, or a subsidiary of this $=>12<24$

Index of local bonds

To see the intensity of the local bonds with the local agents, all the Yes of question (2), but only when these interactions of question (2) were from the local or national area. In other words, the ones that were left outside of international bonds (former multiplying). 


\section{Copyrights}

Copyright for this article is retained by the author(s), with first publication rights granted to the journal.

This is an open-access article distributed under the terms and conditions of the Creative Commons Attribution license (http://creativecommons.org/licenses/by/4.0/). 